ABORIGINAL HISTORY 1981 5:1
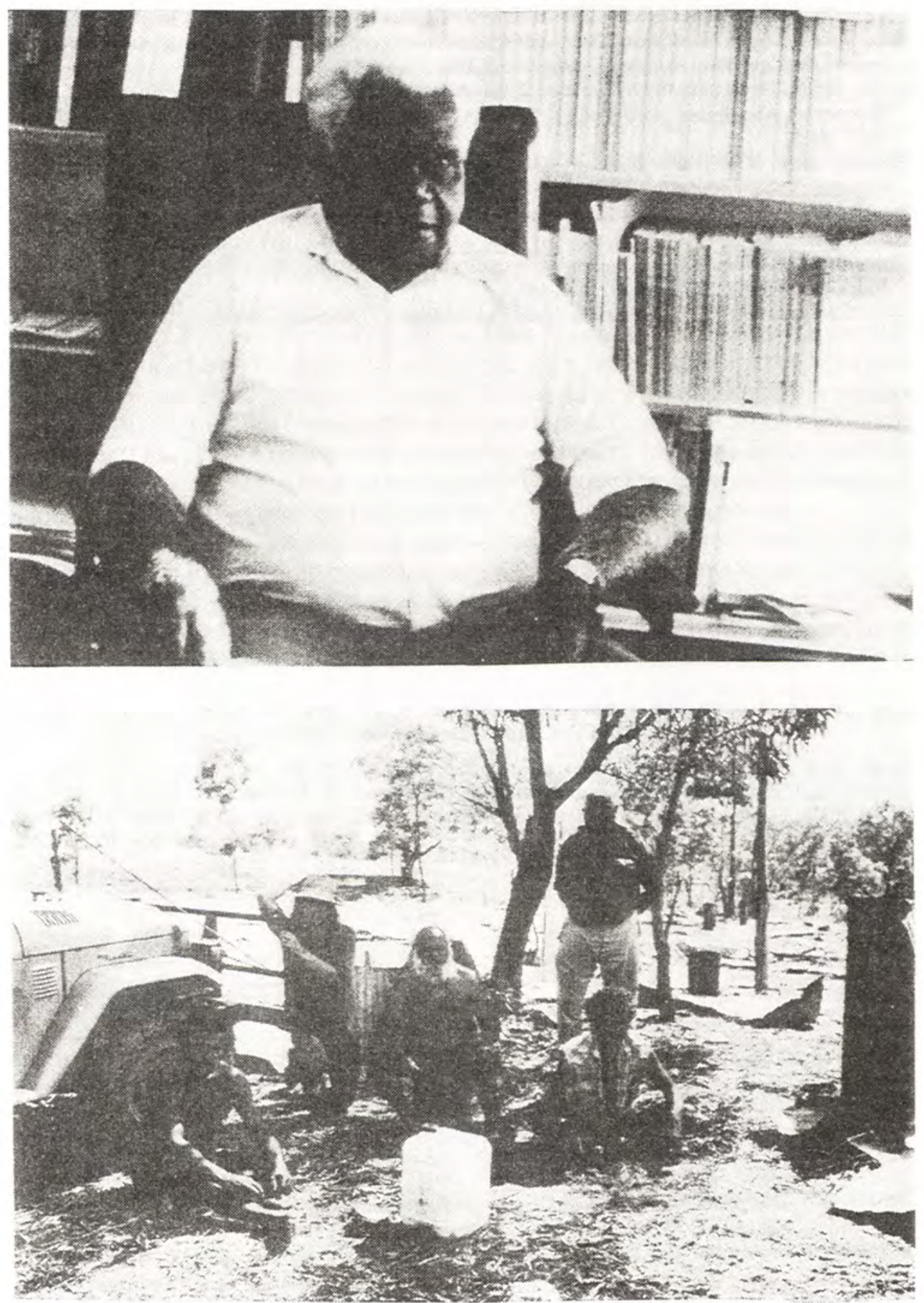

Top: Norman Mitchell in Brisbane, September 1980.

At Maytown, 1979, Norman Mitchell (standing); Joseph Geia, Christopher Anderson, Don Brady, William Brady (left to right at front).

Photographs by Bruce Rigsby. 


\title{
KUBARA: A KUKU-YALANJI VIEW OF THE CHINESE IN NORTH QUEENSLAND*
}

\author{
Christopher Anderson and Norman Mitchell
}

The reminiscences of Norman Mitchell, one of the last remaining KukuYalanji with direct experience of life on the Palmer River before World War II, provide information on Aboriginal-Chinese dealings in the aftermath of the Palmer River gold rush. The period after 1900 is not well documented in the historical literature of this region of Cape York Peninsula and information concerning Aborigines is scanty. In the early part of this century people of three very different cultures, Aboriginal, Chinese and European, struggled to come to terms with each other around Maytown and the small towns south of there, where the three populations were often fairly evenly balanced in size. Relations between Aborigines and Chinese are of particular interest, as the Chinese were the only sizeable group of non-Europeans that inland Kuku-Yalanji had ever met. Apart from observing their habits and way of life, Aborigines were undoubtedly interested to see that another group of people suffered similar discrimination from Europeans.

Norman Mitchell (whose Kuku-Yalanji names are Burrimuka or Babiwawu) was born shortly after the turn of the century at Holmes Creek camp near Mt. Carbine in Cape York Peninsula. His father Ngamuyarkin was a Yalngkurrwarra man from 'Cooktown-side', while his mother Yambakalja, although born in Maytown, was a Kuku-Jangkun speaker from Mt. Mulligan. Shortly after his birth Norman accompanied his parents to Maytown, where he spent much of his early life.

Maytown had been the centre of the Palmer River gold rush from 1873 to about 1885 . The region, then virtually unknown territory to Europeans, was transformed almost overnight by a series of frontier townships and prospecting camps stretching all along the Palmer River and its major creeks. Following the discovery of payable gold on the Palmer River by J.V. Mulligan in June 1873 there was a rush on a scale unequalled in Queensland to that time. By August 1874 there were over 5,000 Europeans and 2,000 Chinese working at the Palmer. ${ }^{1}$ Most of the Chinese had come from other colonies in southern Australia, or from the Queensland goldfields to the south such as the Cape River or Gilbert River areas. As the news (and the gold) reached China, many young men set off for Queensland, often financed by Chinese merchants who then received a large percentage of the men's earnings. The historian Bolton notes that the 'majority came from four small districts in the Kwangtung province, whose men had for some years gone out in similar circumstances to mine, at first for Malayan tin

- We gratefully acknowledge the assistance provided by the Research Committee, Department of Anthropology and Sociology, University of Queensland, and the Australian Institute of Aboriginal Studies. We also wish to thank Jim Urry, Diane Barwick and David Trigger for their helpful comments on an earlier draft of this article.

1 Kirkman 1978a:119. 
and gold, later in Indonesia, North America, Peru and the southern colonies of Australia'.2 By June 1875 the Chinese population of the Palmer River and Cooktown (the port of entry to Australia and to the goldfields for the Chinese) was over 12,000 . Of these $75-85$ per cent had come directly from overseas. ${ }^{3}$

The Chinese miners worked primarily those areas of the Palmer already exploited by Europeans, but by patient and industrious labour they were often able to secure respectable quantitites of gold. In the townships such as Maytown, Byerstown and Palmerville which had sprung to life along the Palmer the Chinese were 'found to provide the community with services which had been lacking or inadequate, some as market gardeners, others as cooks, a few even as doctors or herbalists' ${ }^{4}$ Chinese-European relations on this goldfield were not characterised by the violence shown on the earlier Victorian fields, but discrimination and prejudice were common. European miners, often jealous of Chinese success in areas the former had abandoned, demanded and successfully persuaded the government to implement such control measures as a 'head tax' on Chinese immigrants and special duties on miner's rights for Chinese. The maximum number of Chinese on the Palmer was 17,000 in 1877 , but by 1880 the Chinese population had declined to 3,000 and the majority of Europeans had also gone. ${ }^{5}$ During the 1880 s and 1890 s most of the Chinese who had not already

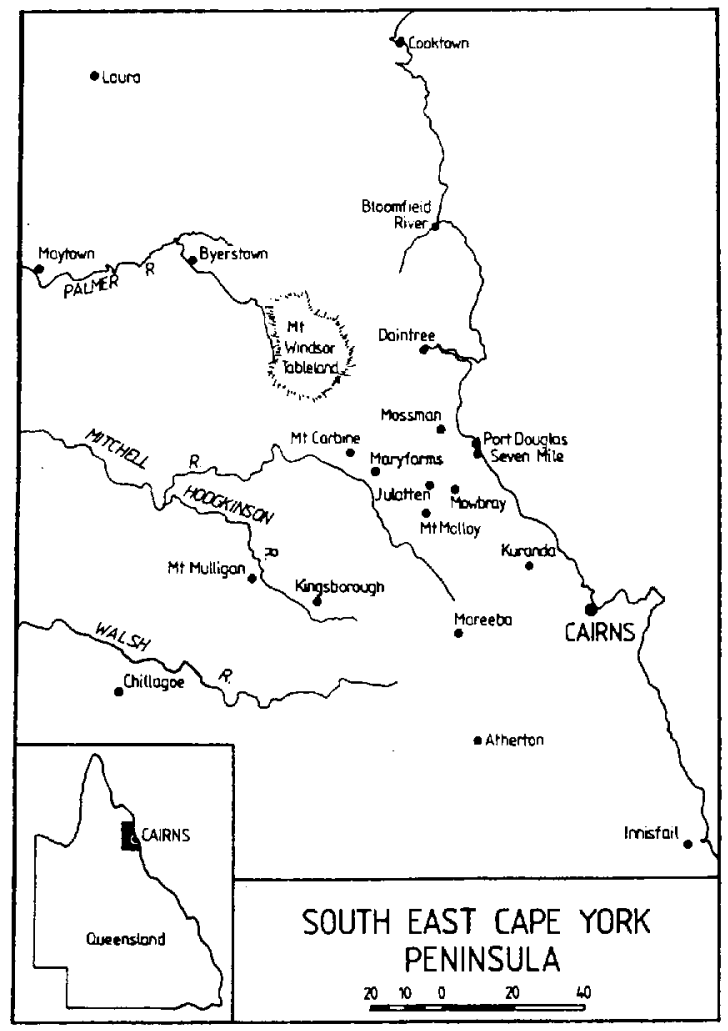

2 Bolton 1972:55-56.

3 Kirkman 1978b:244.

4 Bolton 1972:57.

5 Bolton 1972:60. 
returned to China left the Palmer and moved south to small townships such as Mt. Molloy, Mt. Carbine, Mareeba, Port Douglas and Mossman, as well as to larger centres such as Atherton, Cairns and Innisfail. Only small groups of Chinese and a few Europeans stayed on the Palmer for some years after World War I. Maytown itself was finally deserted and left in ruins. Even the materials from its buildings were taken for use on pastoral stations when the last family, that of the postmistress Mrs Parsons, left in the mid-1940s.

The Chinese who moved to the small towns quickly established a near monopoly on the supply of fruit and vegetables and, on the coast, fish. Chinese who had not become naturalized citizens were forbidden to own freehold land, but many Europeans who lacked the capital to develop their holdings leased plots to the Chinese, who cleared and cultivated this land. As well as supplying produce locally, during the 1890 s Chinese entrepreneurs established a major banana export business, utilising their ties with Chinese communities in Sydney and Melbourne. In 1898 almost forty million bunches were exported from Cairns. ${ }^{6}$ Cotton, sugar, rice and (on the Atherton Tablelands) maize were also grown by Chinese on a large scale.

The everyday life of the Chinese and their dealings with Europeans are well described by May. ${ }^{7}$ It would seem that the aim of most Chinese was to make money and send it home to China for their families. They usually returned to China when they were ready to marry. The Chinese communities of the late nineteenth century showed no real desire to involve themselves too closely with Europeans and their society in Australia. This, coupled with European prejudice, created 'Chinatowns' in most of the larger coastal centres of north Queensland. In fact the approximately 2,000 Chinese living in Cairns during the 1890 s constituted between a quarter and a third of the entire population of the town.

There is no doubt that the Chinese were intricately involved in the north Queensland economy and contributed a great deal to the changes which occurred in this region following European settlement. Yet as May points out:

In the district as a whole, the first decade of this century was a time of flux during which significant migrations of Chinese from area to area were coupled with the beginnings of an overall decline in the Chinese population.

After 1903, the Chinese community in Cairns suddenly lost its dynamism.

An obvious cause was the Immigration Restriction Act of 1901 which effectively caused the Chinese population figures to stagnate. Moreover, the original immigrants in their fifties, were increasingly returning home. ${ }^{8}$

The 1920s saw a brief upsurge in the number of Chinese on the Atherton Tableland due to increased maize production. Vestigial Chinatowns also remained in coastal centres into the 1930s. Overall, though, the Chinese population of north Queensland after this time was small, stable and made up of Australianborn Chinese who intended to remain in Australia. ${ }^{9}$

The initial response of the Kuku-Yalanji and Kuku-Mini Aborigines to the great influx of Europeans and Chinese into their lands on the Palmer was that of fierce resistance and virtual guerilla warfare. The events of this early

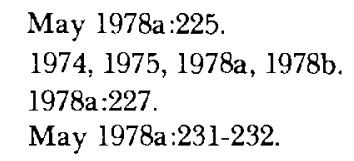


period have been fairly well documented, at least from a European perspective, by various historians. ${ }^{10}$ In the end, the superior fighting technology and the greater numbers of the aliens won out. The remaining Aborigines in the Palmer region were forced into a position of mining camp and town fringe-dwellers and itinerant labourers. With declining gold production from 1885 onwards and a rapid decrease in the European and Chinese population the Aborigines, too, were forced into towns such as Mt. Carbine, Mt. Molloy and Mareeba. Here their relationships with Europeans and Chinese remained much the same. Aborigines supplied labour in return for rations, opium and (rarely) money; some Aboriginal women lived with non-Aboriginal men, and bore their children. Many of these 'half caste' children were removed by police to government settlements or church missions under the provisions of the Aboriginals Protection and Restriction of the Sale of Opium Act, 1897 and subsequent legislation for the control of Aborigines.

The memories of Norman Mitchell and his recollections of stories told by older relatives are of importance in giving an Aboriginal perspective of the Chinese in north Queensland and information on Aboriginal-Chinese dealings in the Palmer area. After spending his childhood in Maytown he came back to Mt. Carbine and worked at pastoral stations on the Upper Mitchell, Hodgkinson and Walsh rivers, as well as mining for tin, wolfram and gold in the same area. He travelled extensively in southern Cape York, working for Europeans, for Chinese and for himself as stockman, butcher, packer, cane-cutter, and miner. He spent time on Palm Island (off Townsville), the Queensland government's Aboriginal settlement 'for those in need of sterner control'. Because of his stockman skills he was later shifted to the Woorabinda settlement, which included a large pastoral property near Rockhampton. During the early 1960s Norman returned to Mareeba, where he now lives. His range of experience - early bush life, the urban settings of Mareeba and Cairns, the government settlements and his extensive involvement with Europeans and Chinese give him a rather unique Aboriginal perspective on culture contact in this area of north Queensland.

Fortunately Bruce Rigsby and I were able to visit Maytown with Norman Mitchell on a University of Queensland fieldtrip initiated by Mr Don Brady, a Maytown Kuku-Yalanji descendant who grew up on Palm Island and now lives in Brisbane. He was anxious to re-establish links with the land of his father and to ensure that information about it was recorded. A grant from the Australian Institute of Aboriginal Studies enabled us to spend several weeks, late in 1979, documenting sites and recording social history in the Mareeba-Carbine-Palmer region. ${ }^{11}$ After the death of $\mathrm{Mr}$ Jack Cummings (Babibulkibulki) at Mareeba early in 1980, the urgency of recording the memories of the few Kuku-Yalanji who recalled life on the Palmer was obvious to all of us.

In September and October of 1980, Norman Mitchell was able to come to Brisbane and work as a language consultant for us in a number of courses offered in the department. In addition, I took this opportunity to expand my knowledge of 'Maytown-side' Kuku-Yalanji language, culture and social history (as most of my other fieldwork has been with coastal Kuku-Yalanyji around 1974.

11 See Brady, Anderson and Rigsby, 1980. 
Bloomfield River). It was during this time that Norman and I recorded the information presented below on the Chinese of North Queensland.

The following text, and the commentary in its footnotes, provides something of an Aboriginal perspective on the Chinese in north Queensland and presents information on Aboriginal-Chinese dealings in this area. Precise dates for specific events described are difficult to establish, but the general period which Norman is describing is roughly from the end of World War I to the beginning of World War II except of course when he is referring to stories told him by his older relatives. Norman is a fully fluent speaker of KukuYalanji, but his everyday speech in Mareeba today is Cape York Aboriginal English. We thus recorded his narratives primarily in the latter, although where appropriate Norman also gives the Kuku-Yalanji word or phrase. Some of the text, as may be apparent to readers, is the result of my questioning and promptings. My remarks have been omitted. Some sections of the text have been reorganised to bring together material on the same topic, and some information collected on our 1979 trip has been inserted for clarification. Norman Mitchell, who has taught himself to read and write in the last few years, checked my editing and re-organisation of the transcripts of his taped narrative and has made corrections where necessary. Names of some persons, particularly the Chinese, have been changed where an incident may embarrass any living descendants.

Finally, two things require further comment. Relations between Chinese and Aborigines in North Queensland often involved the exchange of opium. The Chinese brought it with them into north Queensland and continued to import it legally until 1906, and illegally until well into the 1930s. Their use of it was by most accounts moderate. ${ }^{12}$ The Chinese were in fact, as Bolton notes, probably 'too thrifty and self-respecting to become addicts'. ${ }^{13}$ It is clear, though, that Chinese (and many Europeans) did use opium as a means of attracting and keeping Aboriginal labour. ${ }^{14}$ Primarily because of the form in which it was taken by Aborigines - opium ash mixed with water and swallowed opium did affect their health. Archibald Meston and Walter Roth, Protectors of Aborigines late last century, both commented that opium was responsible for 'thousands of deaths' and exerted 'a far more baneful influence on the aboriginal than even liquor and venereal disease'. ${ }^{15}$ The notion was widespread among Europeans that from the time Aborigines began to use opium they became 'saturated with the noxious drug and degraded beyond all explaination [sic] ${ }^{16}$ Although opium was indeed a factor in the generally very poor health of Aborigines in north Queensland, it is likely that Europeans too readily blamed the presence and involvement of the Chinese, who became a scapegoat in explanations of the appallingly high death rate of Aborigines. The historian Evans says that 'the rapid spread of the habit [opium addiction] throughout the colony, plus its oriental origins and bizarre effects led observers to brand it

16 Cronin 1975:308. 
overwhelmingly the main destroyer of the semi-civilized black'.17 Thus any European guilt about the condition of Aborigines was assuaged. Many Aborigines in North Queensland were removed by police to settlements when charged with possession of opium, but its use by Aborigines seems to have stopped altogether by World War II.

The cannibalism allegedly practised by Aborigines of the Palmer River area is another matter requiring special comment. The existence of such a custom is virtually taken for granted in much literature on the Palmer and is uncritically believed by many Europeans today. Popular belief is aided by books such as Hector Holthouse's River of gold, which argues that 'In country where an uncertain supply of wild game provided either a feast or a famine, they were all cannibals of a particularly bad type'. ${ }^{18}$ Holthouse then quotes an unnamed source who says: '[The Palmer Aborigines] killed and ate their own women and children, and occasionally their men. The older women were often killed for eating purposes like livestock'. ${ }^{19}$ And later: 'To the cannibal blacks, the new chum Chinese were manna from heaven. Hundreds of them were ambushed, captured, and eaten at leisure in gloomy canyons like Hell's Gate, at creek crossings, and in patches of scrub along the track', and 'Captured Chinese were taken ... by the dozen and hung on trees ... by their pigtails until they were needed for killing and eating', ${ }^{20}$

Although fairly solid ethnographic evidence exists for the eating of human flesh as part of mortuary practices in the eastern Kuku-Yalanyji areas around Bloomfield River, ${ }^{21}$ there are no reliable reports of this or any other sort of 'cannibalism' on the Palmer. It is certainly nonsense to suggest that human flesh was a basic source of food. Hughes states that 'Actual evidence of cannibalistic feasts was rare - obviously the only concrete evidence could be half cooked remains - but the widely accepted belief that the Aborigines carried off the corpses of their victims gave some credence to reports of cannibalism'. ${ }^{22}$. The Cooktoun Herald reported that 'the increasing appetite of the [Palmer] Aborigines for roasted Asiatic is one of their marked peculiarities'. ${ }^{23}$ Bolton remarks that 'many old-timers assert that the special hostility of the Palmer natives towards [the Chinese] was due to a belief, quietly encouraged by some Europeans, that the vegetarian Chinese made better eating than white men'. Bolton goes on to say, however, that 'The very few accounts of Palmer cannibalism which sound in any way authentic certainly suggest a preference for Chinese; but there is not much good evidence to go on, and as many Chinese travelled unarmed, they were in any case easier victims to hostile spearsmen'. ${ }^{24}$

My own view is that the eating of human flesh probably did occur on the Palmer, but in very particular and limited situations. One of these was probably the ritual consumption of parts of a slain enemy - and after 1873 enemies 
would have been numerous. Apart from the probably rare actual incidents of human flesh consumption, the strong European belief in Aboriginal cannibalism in this area arose and persists today, I would argue, as an ideological defence mechanism: it states and reinforces the belief that Aborigines were less than human or at the very least were 'uncivilized' (if they ate other humans). This then justified their removal from the land and their extermination. The spectre of indigenous cannibalism has been used all over the world to justify colonial violence. ${ }^{25}$

Nevertheless Norman Mitchell's account of his grandfather telling him a story of how he killed and ate a Chinaman is given in good faith. Cannibalism has entered the contemporary Kuku-Yalanji belief system as fact in the same way it has with Europeans. Elderly Kuku-Yalanji people will tell you with quiet humour and pride of the fear engendered in Europeans and Chinese by such legends. And if nothing else they are proud of the cultural distinctiveness and active resistance to alien intrusion which such customs demonstrate.

\section{Memories of the Kubara}

We call Chinaman Kubara, ${ }^{26}$ or sometime mira bilin ['tight eye']. When they first come out here they had that mungka biji - 'pig tail', you know. And those that lived around Maytown, they was all like that for a long time. And even when they come to Mareeba they lived like that. Most of them had this long hair and that long moustache for a long time and then they gradually give it up. Some of them used to cut themselves baldy.

All the Kubara, they started off gettin' gold on the Palmer and when that finish they come to [Mt.] Carbine. Most of them stopped at that place Diyalmbayn ${ }^{27}$. Ooh! There was thousands of them there! (Chuckles) Nearly on top of one another! They had a big garden there, cross the creek, right up on the bank. Good vegetable garden too. Tomatoes and shallots, Chinee cabbage . .. they sell'em. They [went] up and down there from that place to Carbine and Molloy. They had plenty a rice there Carbine too. Storekeeper sent oversea to China for it ${ }^{28}$ From there to Mary Farm. Big mob was there too. Grardens there. And they gradually musta found a way ... well, police probably was the immigrant ... whatee call it ... supervisor and so forth. They turned around and musta told'em where to go. And then they went to Mareeba, most of them. Some in [Mt.] Molloy. Some in Julatten. Some went down Mossman, Daintree.

25 See Arens 1979.

26 Dr David Ip of the Department of Anthropology and Sociology, University of Queensland has pointed out to me the similarities between the word kubara and the anglicized spellings of a Chinese word which was often used as a name for Chinese shops. The word is $G A B O$ (GA, the honorific, and $B O$ meaning 'treasure'). It was thus used, as in 'The Treasure Trading Company', and anglicized spellings were 'Karboro', 'Kaboro', and so on. Usage of such a word by Aborigines in referring to Chinese relates well to the common north Queensland Aboriginal belief of great Chinese wealth and of buried treasure left by the Chinese.

27 Place on Holmes Creek north of Mt. Carbine.

28 Although there were several major attempts to grow rice in north Queensland - some utilising Chinese capital - these were largely unviable due to low-cost imports. See Bolton 1972:224-225. 
Like that, see. Scattered all over the country. Ooh! there was a mob of them. Some fella went Cooktown. They start gardening there and then they made joss house there. They ended up pulling the old joss house. Was way down near the cemetery, it was. Then they took all the gear, the joss thing, into the whatee call it, museum there Cooktown. 'Nother joss house bin there Port Douglas too. Gone now. I don't know where they put all those joss things Chinee instrument, crackers and all that sorta thing.

I was out at Carbine when they come in to Mareeba. When I come Mareeba, oh! there was hundreds of them. All around Mareeba. Right up, nearly to Carbeen..$^{29}$ And up to Granite Creek..$^{30}$ They had gardens of course. They went in for gardening. Most of them come to Mareeba with packhorse team. Charlie Ah Tong, he had a team of horses. Also Kwan Lee, a big Kubara. And Tam Chan ... he had a team of horses too. Two brothers, there were Tam Chan and Gum Chan. Little short fellas. Little bloke. Charlie Ah Tong was a short, nuggetty fella. A great horseman too. Butcher up that way in Maytown. First on Nelson Creek, ${ }^{31}$ then right up near old Byerstown.

Charlie Ah Tong lived in Carbine a long, long time. Till Carbine broke down, then he went over [Mt.] Mulligan. Lived over there and so did Tam Chan and Gum Chan ... they went up around Chillagoe. One brother had a garden there near Kingsborough until he went gold-scratching around there Mulligan side. ${ }^{32}$ Then after, I don't know where they went to ... or what they did with their horses and pack teams they had. Old Chinee, old one-eye Ah Lee. He had a pack team. He was one of those big business fellas. He buy from others and ... that's how he make money, ${ }^{39}$ then after, go over China then. Sold all his pack team and went through. Then there was another fella down at Molloy ... old Tie. He had a garden up there at Spear Creek..$^{34}$ He stopped up there. Bought some gold from that old [Aboriginal] fella . . old Harry Kludo, I call him ngaji ['mother's father'] see, he belong to round Mt. Molloy too. Old Tie went down to Mossman and lived with a Bama [Aboriginal] woman there, Wayil-baja from Boggy Creek. ${ }^{35}$

When Kubara first come this country, Maytown was very big place at that time. What we see now is just nothing (chuckles) to what it was in the days gone by. Kubara, Waybala [Europeans] scattered all around there. Houses everywhere. Right up the Palmer. Big Bama camp too, later on. Lotta Chinee there Byerstown too. Used to be big township there. Chinee township near Byerstown on the junction of Blackfella Creek and the Palmer. Blackfella Creek come in from this side [south] and Spear Creek from other side [north]. And they was just on the bank, on a big open flat like. Chinee storekeeper, butcher, packer-team and some fella still gettin' gold.

Small pastoral property near the Palmer River.

Creek flowing into Palmer River from the north near Maytown.

Creek also flowing into Palmer River.

Following the demise of the Palmer, many Chinese went looking for gold to the south and west of Mareeba, then eventually on into the Northern Territory

May (1978b) discusses the strong intra-group and kinship basis of Chinese merchant activity.

Creek north of Mt. Molloy.

Boggy Creek was an Aboriginal Reserve on Butcher's Hill Station (now Lakeland Downs), southeast of Laura. 
We used to go up there ... don't know whether Dad used to take the opium or not . . . but we used to often go up there to Chinaman garden, you know. Give the Chinaman a hand, shiftin' grass, weed. ${ }^{36} \mathrm{Had}$ a big garden growin' there and so forth. Dad used to bring 'em great big sand goanna. He used to grab 'em by the tail and slap 'em on the ground. If they go in the water, he'd grab 'em by the tail and whack 'em on the head on the stone. Chinaman would eat that minya [meat food] then. They use that fat part, oil, too, for all kinda cookin' and so forth. And they mixed in that samsu $u^{37}$ - Chinee rum they call it. They used to have it for purpose of medicine too.

I don't know whether they brought any minya [animals] with 'em when they come from oversea. They used to eat kaya $[\mathrm{dog}]$ - fatten 'em up, then eat them; pussy cat too. Biki-biki [pig]. They used to get a lot of it out there Maytown. Bulki [beef or cattle], too. But the way they cook it. Had different way. Their own way. 'They make the taste . . . food very tasty. Sometime for cookin' they use a kurrma [stone oven in ground] after they learn from Bama. But mostly they put minya on a, whatee call it - grid thing - wire with handle on it. Fire come up from bottom. They stuff minya with mayi [vegetable food] inside. Sew it up. Rice and vegetables sometimes. They used to use the joss [chop] sticks (chuckles). Eatin' their mayi [food] very quick you know.

Hot! They like hot meal. Most of the Chinaman used to drink tea, binju [unsweetened or strong] tea. We call it marru up that way. They had their own Chinee tea. They like green tea. Taste like green [vegetable] too! Chinee tea is very strong though. Powerful. And they used to take to it and make themselves strong and things like that. They were very proud of it, you know, - how they do their cooking and things like that.

In the by-gone days, Chinaman had medicine that they learned 'bout over there. Whether they had sandalwood over there in that country I don't know. ${ }^{38}$ The first thing they took here was the sandalwood. Used it for medicine, see. Good for veneral disease, whatee call it, 'gonnearo'. You had to boil it up. But they made it th'other way round. In the old days they would scrape all the goodness down [off the sandalwood] and then strain all the stuff out - the medicine part, the juice part. Then they made all the waste into ... didn't waste it ... They scraped and made it very fine. They made those joss sticks out of it then. And it was very handy, they used it for everythin' then - like a candle; they used it as a candle light. They powdered the stuff down, like sawdust and

36 Aborigines regularly worked for Chinese, mainly as manual labourers, even after the $A$ borigines Protection Act of 1897 made it illegal for Chinese to employ Aborigines. Roth (in Queensland Parliament. Debates, 8 Oct. 1901:1141) reported that 'Reputable Chinamen are amongst the best employers of aboriginals - they do pay them their wages'. Bolton (1972:229) also reports that 'many Chinese also supplied opium to Aborigines in return for services of one kind or another'. Attempts to prevent Aborigines from working for Chinese were related to the general belief that the Chinese 'harboured' Aborigines and 'degraded' them through vice and disease. It probably had more to do, however, with European farmers and pastoralists wanting no competition for Aboriginal labour (see Barron Valley Progress Association to Colonial Secretary, 15 July 1898, Queensland State Archives (QSA) COL/139; see also Cronin 1975:252).

37 'Sam Shu', according to Bolton (1972:229) was 'an extremely potent drink' often served by Chinese storekeepers.

38. At this period the sandalwood used was probably imported from the Pacific rather than China. 
they put some other stuff to make that light come on. Slow burning process. That sort of thing.

Then there was lots of other medicine too. Lemon juice. They ... used that skin part. Either eat it or use it for people with fever or something like that. Course they must mix a bit of sandalwood too. And gallstone, goanna gallstone. Goanna oil and fat. They mixed it all up and used it for rheumatism or back ache, anything like that. That sorta medicine. They made it because they musta knew over there in their country.

Most of their religion was ... what that animal there? Dragon. They used to get down and pray in Chinee language and that sorta thing. They had their dreamtime story too, these fellas. Used to talk about it to our people, you know. They used to talk about their country too. Lots of them believe in this, whatee call it . . . they were most of them witchcraft Chinaman, you know. And they believe murri [Aboriginal] way too. They got this one [makes sign language for sorcery] and medicine poison too. Get that tar from a tar tree. Leave it in water soakin', till it all dissolve. Then they put it in tea or a drink. Put it in opium or something like that. Bin goin' on for donkey years. One fella give it to 'nother fella and that fella get sick. They had 'mussing' too [love medicine] But they brought it over from their own country. A weed sorta thing. Used to use that for a long time. And finally they forsook it. Worked for [getting] Bama jalbul-jalbul [women] too.

Chinee fella didn't have much time to waste. They were gonna go straight back oversea, but they were allowed to stop in the country a little bit longer to do what they wanted to do. Some of them made up their own mind and stopped here. And they made business and so forth, like that. Those fellas who left took the gold with them. They must have, because they wouldn'ta gone through without any. ${ }^{39}$ Because there was nuggets in those times. Sometimes, the Chinee women went oversea ... those what come out there in Maytown, they went oversea and got away. Story I heard was they used to get a rubber thing, put that gold in it and push it up their mabu [vagina] part, you know. And then they go to get on the boats somewhere Brisbane or Sydney, Waybala couldn't find anything on them. They got the gold out and took it oversea. Old country then. Old fella Chinee laughin' then, sayin' 'Good thing we had our women folk, 'cause of them ... they brought that thing [gold] over a lot cheaper than we'da brought it over'. In other words they sent for a lotta young girl, so of course they come out. Just come pretend to see their people, but they got away with the gold.

They used to use a jar too, there Maytown. Lot of them lyin' round before. Belong to Chinee. Big as that box [tea-chest] there. Most of them they used to put dead body in that jar and send'em away. Sometime send gold too. ${ }^{40}$ Lot bin there Nelson Creek. Two big jar with body still inside. Hide like a

39 Bolton (1972:55,58) notes that in 18743,586 ounces of gold worth $£ 12,959$ (apparently all from the Palmer fields) reached Canton and Hong Kong. In 1876 and 1877 more than 100,000 ounces (worth about $£ 400,000$ ) were exported through official channels to China. In 1881 , when the rush days were over, more than 10 per cent of Queensland's gold exports still went to China.

40 These large earthen clay or ceramic jars were used as containers to ship a deceased person's remains back to China. Bolton (1972:58) states that: 'It was apparently particularly common to secrete gold-dust among the remains of dead Chinese shipped home for burial among their ancestors in the hope that pious or squeamish officials would refrain from investigating'. 
leather, all dried up. Bones still there, all broken up in pieces. They fold'em up. Then when all that give way - all the body part - well you just see the bone then. Foot bone, knee, all the joints. Everything in that jar. They musta put something in to purify the ... stinkness or something like that. They musta brought some stuff from overseas. No $k a b u$ [smell]. They could leave it there for months. It'd never stink. Or a year, two or three years, five or six year. Twenty year, thirty year, forty year . . . Forty years might'a been.

When I went back and worked on Brooklyn ${ }^{41}$ again, I went back out that way. Found those jars still on the goldfields. My old boss, old Fred Dawkins, he took the head part outa one jar and that thing bin drive him mad. (chuckles) We bin have a fight then. (chuckles) I think birru, spirit, musta made him wild. He had a buster off the horse and nearly got killed. Well, we went away for a holiday then come back and that drovin' [trip] we had a fight. He tried to double me up. He musta had that thing ... someone told'im about that there were ... make him lucky or something, that Kubara head part. He carry it about for long time. Horse fell with him. Nearly broke his neck.

They're very cunnin', Chinaman, you know. Old See Poy there Innisfail. Before, he was in Palmer River too. He bin there Nelson Creek and right down the branch and over Hurricane [Creek] and all that sorta place. When the Palmer River close down, he come down then. In a olden time bullock team. And his family. He got a bit cunnin' in a way, you know. And saved enough money to buy that store in Innisfail. The son runs it. He's a big-shot now. Started his life's history in Palmer River gold rush. ${ }^{42}$

Chinaman made those joss things and crackers oversea and sold them in this country. Made lots and lots of money that way too. Very cunnin'. They live very hard and they had a lot of money put away. Tucked away. They carried money hidden in a tin or bottle something. When they're ready to go, they got money. They go through a long way. Some of them worked for such and such time and they had this ... thinkin' they'd get rich ... witchcraft sorta belief, and they got it too!

One old Kubara bloke, he was with Paddy Julian, stayed there Spear Creek. He wanted to book some tucker down the store. Old man Jubilee now this old Waybala Jubilee wouldn't sell him any, wouldn't book anything. Alright. When he ready to go through, the day before that ol'Kubara said 'I wish I'd get some mayi". Went down there to store with ooh! about four or five thousand pounds [sterling]. Right through to Cooktown. Walked from there. Went to Cooktown and he was gone. Oversea with all that money. They had that sort of gift.

One murri fella, old Jack Lawyer, he used to be a lawyer for Chinaman..$^{43}$ He was a tracker too. When the Chinaman used to go to court, those who could not speak good English, Jack would come there. They'd send for him. They'd

41 Brooklyn Station north of Mareeba.

42 Taam [1925] 1970.

43 May (1979:163) discusses the important role European lawyers and business managers played in acting as intermediaries for the Chinese in the Cairns area. Such Europeans were used by the Chinese in dealing with most official matters especially where language was a problem. Given this pattern in the urban areas, it is easy to see how Aborigines speaking both Chinese and English would be used in the more isolated bush areas and small towns. 
send for miles and miles away for him. To fight the case for one Chinaman, maybe two Chinaman. Tell how the fight went on and all this for those Chinaman who couldn't explain the word properly. So they got this ol'fella to interpret them. He'd talk to them in their kuku [language] first and then found out who was the first started it, the cause of it, so the wrong fella wouldn't get the blame or the dead Chinaman maybe get'a blame first. Then ol'Jack would tell the buliman [policeman] the story.

Louie, ol'Jack's brother, he could talk that Chinaman kuku too. And ol' fella Charlie Dawn. All that family now, they could talk pretty good. They musta learned there when they was workin' for Chinaman at Palmer River.

Chinaman used to live with a lot of women, Bama women, but never married them, you know. ${ }^{44}$ Fella called Lum-Die. Chinaman called Lum-Die. He lived with ... lotta Bama. That ol' [Aboriginal] fella who lives at Mary Farm now? Old Paddy Julian. His father was named Julian, a big up-standing Chinaman. And Uncle Rupert's mother was living with one. Peter Burn's granny ... ol' fella Billy Charcoal's wife. She had three daughters by Chinaman. I think they're over there in Yarrabah ${ }^{45}$ now. And ol'Jack Lawyer, he had stepdaughter. She's half-caste Chinee. Old Billy Tangabura from up there Boggy Creek on Laura River. His people used to hide up on Mt. Windsor to keep the half caste [Aboriginal-] Chinee kids from the buliman. If Bama woman was found with half caste Chinee baby, they both got sent to Mission. Ol' Charlie Snyder. His wife bin sent to Monamona ${ }^{46}$ Mission.

Bama bin get this ... whatee call it ... bin come from Chinaman first ... whatee call it ... 'lepers' [leprosy] ${ }^{47}$ Bama wouldn'ta had 'lepers' before. Our people were clean! And medicine ... . bush medicine. Everything they ate was clean. Jalbul [Aboriginal women] bin get that veneral [disease] first. Chinaman give it to jalbul, then they had children after children, breed up ... but . . . thousands and thousands years, they never had nothing. Our greatest people [i.e., our old ancestors], they never saw such thing in their life. Later, Bama see that the spot come on them was through the Chinaman and his children. Buliman couldn't shift Chinaman unless the government said so. Although they tried to fight hard to keep them away ... but they had that much expanding ... up in that

Following the Aborigines Protection Act of 1897 marriage between Aboriginal and Chinese (as well as European) people was only allowable with approval from the Chief Protector of Aborigines. Cronin (1975:311) states that Archibald Meston, Protector at the turn of the century, had a 'personal abhorrence of miscegenation'. He felt a particular repugnance for Chinese-Aboriginal liaisons. He wrote: 'Our marriage has no meaning to a Chinaman. The Chinese have killed many hundreds of aborigines with opium, and it is asking too much that the unfortunate race thus cruelly wronged be asked to supply women for their deadliest enemies' (Meston to Home Secretary, 14 September 1901, quoted in Evans 1969:66-67).

Yarrabah Aboriginal Community south of Cairns.

46 Monamona Mission in Kuranda which closed down in the early 1960 s.

47 Cronin (1975) make the comment that the "Chinese were continually singled out for debauching and infecting Aboriginal "girls" with loathsome diseases and were regularly censured for "harbouring blacks" for "immoral purposes" '. (See B.H. Purcell, Brisbane, to Colonial Secretary 1891, QSA, COL/A717, in-letter 14199; also Inspector Police, Cooktown, to Commissioner Police, 30 June 1898, QSA, COL/143, in-letter 08420). The Chinese were seen generally (by Europeans as well as Aborigines) as bringing strange diseases to north Queensland. See Brown (1979) and Cronin (1975:302-308) for good descriptions of the fear created in the minds of Europeans over the Chinese and leprosy. 
part especially. They brought the disease in and from that time it swept through like a fire, a bush fire in the grass. Chinaman always gettin' in trouble with buliman over living with Bama woman.

Kubara was cunnin' with Bama. They start given' em opium. ${ }^{48}$ Sometime Chinee rum. That sorta thing. They lived there Maytown. They let the [Aboriginal] women live there. The [Aboriginal] men go then and work for a bit'a gold for the Chinaman. That's where a lot of the Chinaman got the gold from. From Bama.

Chinaman got that opium sent over to them from oversea. Because they were allowed to bring it over that time. ${ }^{49}$ Too many of them here livin' that way [on opium]. Waybala couldn't stop'em. They had it up here first in Palmer River, then around Maytown. Ah Gee and his brothers were storekeepers and bakers. All that sorta thing up there. They were mostly English-speakin' Chinaman. They musta learned over there first, before they come out. But they sold that opium in the store sometime for the purpose of a bit'a gold. They made deals with their own friends; relations.

Waybala had opium too..$^{50}$ One fella Leroy, Kelly Leroy. He used to go out towards Mowbray on a bike. Old Leroy. He was from Carbine. Related to people called Peterson. They were in Carbine too. I think they had something to do with sly grog turn-out. Leroy was their nephew. He used to go to Mowbray. Push the bike out there. Might get a lift out there with one of them trucks. He'd take his bike then come back that way, see. And fella called Eddie, Eddie Chang. He was selling opium then, and another fella called Tommie Chang ... no, he was Eddie too. He was up there living down Bonny Doon way. ${ }^{51}$ He used to work in the mill sometime or cut cane like that. But he was buying opium from overseas. They used to smuggle it there.

When they start to look into this and they wanted to clean it up ... you know ... the police and then ... they gradually woke up [to] where the fella was gettin' it ... this opium. Policeman called Herb Hawkins. He done the same thing as old Leroy. He rode out to Mowbray or Little Mossman, I think. He had a bike, push-bike, waited there and then he caught Leroy comin' home. Grabbed him and searched him. Found it [the opium] then. He used to carry it in a ... those times ... had whatee call it ... wax match ... well they put it in a matchbox see. Not only one box, maybe two, three box or a little round tin with a lid on it.

48 It is important to remember that the full title of Queensland's first Aborigines Act was The Aboriginals Protection and Restriction of the Sale of Opium Act, 1897, and the Act specifically dealt with the injurious effects of opium on Aborigines.

49 The Chinese were allowed to import opium freely into Australia until 1906, when it was banned (May 1978b:230). See also Cronin (1975:310) for discussion of earlier attempts to control Chinese use of opium.

50 Cronin (1975:309) gives supporting evidence that Europeans not only used opium themselves, but sold it to Aborigines and used it as 'wages' for the latter when they worked as stockmen on properties. Meston, in 1901, remarked to the Legislative Council that he had seen opium sent to properties 'in every conceivable form', even in '... the barrels of a double-barrelled muzzle loading gun' (in Queensland Parliament. Debates, 23 October, 1901:1422). Others stated that it was not just pastoralists but '... nearly every carrier, banker, many of the swagmen and some of the mailmen' who were selling opium to Aborigines (E.R. Baker, Mitchell, to Colonial Secretary, 27 July 1897 QSA, COL/140). See also Bolton (1972:252) and Evans (1975:94). The incident described here happened in the late 1930s.

51 Bonny Doon Station southeast of Maytown. 
Ol' [Aboriginal] fella Baldy Mossman. Bama call'im Babi-kalbuwu. Leroy the fella who got ol'Baldy into strife. Teached him 'bout that opium and wild drinkin'. Baldy used to go to Cairns to get it. Police found out Leroy was involved in it. Court found the full strength of it then said 'Aw yeah. That Baldy Mossman in it too'. So they picked him up. Jerry Coen, related to my wife, only a young fella. They took him away too. Found out that he was losin' time. Work on the farm. And they said he must be takin' opium. Gradually they put off with him. 'Nother fella, call'im Freddy Kelly. They used to call him 'Emu'. Great runner, footballer. Little short fella. He was taken in too. They pick up that whole crowd one time, only from that opium now. They want to pick me up too. Old Sergeant Renati. He was Italian fella. But he missed me. Nevertheless, they got theirs back ${ }^{52}$ (chuckles). When they took ol'Baldy middle of the night, they took his whole family, old Mabel and little boy, little girl. They grew up Palm Island then. All because Waybala bin sell'em opium. When they caught Leroy he turned around and dobbed him [Baldy] in.

Bama didn't stop there then . . . up the Grorge ${ }^{53}$ yet. Was still down the Johnson camp, call it ... half-way up to town [Mossman]. Straight over the river there. In the middle where Waybala used to get the sand, well Bama used to camp down there. There was an old slaughter-yard down there. After, they shifted from there up to, where that hill, where water reservoir now.

Opium pretty dear for Bama those times. Five pounds and you get only enough to fill a milk tin. ${ }^{54}$ That didn't last too long when you gotta share it around to big circle of people (laughs). Not even proper stuff either. The Chinaman used to use it first, see. They used to mix it up with tobacco ash, then chew it up. Then, after, they give it to Bama. ${ }^{55}$

This Eddie Chang was a big businessman. Tom Chang had a car tradin'. He had a motor garage in Cairns there. He used to buy it [opium] for the sake of his brother and then his brother didn't use much of it. Smoke it sometimes. But [he] thought, well, easy money to make it by selling it. Selling it to different Chinaman. They ended up havin' big business. One fella, Ernie ... father was Lee Poy ... he was biggest shot around Cairns district. Had big shop and did lot of business with everyone around. Used to sell opium to that ol'fella Baldy sometime. That ol'fella go and pick it up. Come half-way near Seven Mile and get off there. But they gradually found the full strength of it then and picked him up. That's what happened.

'Nother time. That ol'fella now ... King ${ }^{56} \ldots$ old man Jurrumbu Big ... big man, he was solid and used to take that opium for a long time. Too much of that stuff. They put him in hospital. But Bama musta catched him [i.e.

Norman was later sent to Palm Island for hitting a station boss who was horse-whipping a tied-up young Aboriginal man.

53 The present-day Aboriginal community at Mossman Gorge.

54 May (1979:230) notes that the banning of opium 'rather than preventing importation,... raised the price of contraband opium'. She states (1979:235) that in 1908 the cost of one ounce of opium was 10/- to 12/6 (Cairns Post 27 November 1908).

55 Evans (1975:94) states: 'Natives were sold, in small packets, opium dross - the ash which remained after the opium itself had been smoked'. This 'charcoal opium' was said to be stronger and have a more deleterious effect on the user.

56 'Elders' were often given brass plates by European police and were then known as 'kings'. 
sorcerized him]. When doctor cut'im open [in hospital] they found that, whatee call it, 'Lockhart' [Leichhardt] leaf and that kurma [hot, round stones]. That's the only way they caught him see. Not that opium. He was pretty wasted way on that opium. When it happened this old man, Bujal now, I call'im mukay ['father's older brother'], see, from up that way Cooktown. He had it on old Jurrumbu for 'killing' his wife ['letting' his wife die]. ${ }^{57}$ So he and other wife's son caught that ol'fella and put a kurrma in him [sorcerized him and put hot stone(s) in him]. When doctor operated on that ol'fella then, they find that kurrma still there, hot! That's right, birra [leaf] too. 'Lockhart' leaf. Thought: 'How did these leaf and stone get in here?' They think this fella only sick from that opium. Really done by the devil power.

One old fella ... but he was dimuriji [had power of 'devil' spirits] this fella ... they found him dead from opium. White fella found him. The police saw maggots and everythin' comin' out of him. That very same day we was workin' up at Seven Mile, Mowbray, police come to tell us. But that night we was sittin' down at a big fire. One old fella sing out, 'Whoa! There's that fella walkin' now'. We saw him walkin' there all white, like that, what you call 'em ... like that niece mine up at Mossman ... albino. No matter that opium kill you, Bama still gettin' round.

To take that opium you put it in the water in a billy can or one of those kerosene buckets. Gets like dirty water. Bama all round in a circle. I took to it too. Just like smoky water . . like it come off the roof. You pass it round, each fella has a turn. Some fella pannikin, some big fella pick bucket up. That old man now, Jirrumbu. He big man, pick the bucket up to drink. Kanya Harry and all them fella now. One fella there, Tommy somebody, Tommy Butha. He musta went back and died up that way. He lived on it [opium] for a long time.

It's not like that kamu-kamu [alcohol], make you go silly. After when it [opium] affects you, sorta makes you very drowsy, want to sleep all the time. Then you just like a wet rag. You know, arms, legs all down that way. You might get a dream sometime. I only had a go at it when I had a 'flu'. My brother-in-law gave me. But, oh, it'll give you a good old sleep! Feel no movement and have a good old sleep. Fresh as a daisy when you get up then. Full of go. Ooh! a lot of people took to it for a long time. Woman too. Some of the older ones, that's why they bin die, a lot of them. Then after awhile they stop when Chinaman shift from there. Most of the Chinaman around Mossman, they couldn't get it anymore and then Bama had to give up. Went to grog then. Then that's how they died, after, you know ... It's the pressure of it. Sort of work through the grog too see... take Bex, you know. Give you all kind of disease, sores and so forth.

One more thing. Old man ... Banjariba, Bama name. Charcoal ... Ngambanyarimba. They call'im Billy Charcoal. Well I think he worked for people called Pitt who were in Maytown in by-gone days. Ol'fella only work now and again. He was free. Mayal wil'fella ['wild' Aboriginal], if he wanna walkabout a lot. Still lota Chinaman then. Big fella too, big-boned bloke. Little Chinaman, he could pick'em up. He would pick up Chinee fella and tie their hand together and put'em up in a tree until such time, until they were almost ... dyin' away. And then he'd come back and then put a spear through 'em, when they were 
startin' to get weak. Pull 'em down, and cook 'em. You got to make a medicine though. Jana dimur [those devil-spirits] watch you. They get Bama 'less they take care eatin' Kubara. Boil it down and when all the juice is washed down, drained out, put it all over themselves, those ol' people before they eat. Rub it like. That smell take the spirit [of the dead man] away.

Lots of other fellas too. I forget a number of them. Biggest part of that Kuku-Yalanji mob. Wil'time and after too! (laughs) Babi-duburrbu, old man Charlie Curraghmore's father. He wil'fella too. Old man Pegas, he wil'fella. He bin eata Chinaman too. I bin ask'im: 'Kami, yundu Kubara nugan?' ['Father's father, did you eat Chinaman'] [He answers:]

'Yuwu! Wanyurringku?' ['Yes! What's the matter?']

[Norman asks again disbelieving:]

[He answers:]

'Wanyu Bama nugan?' ['What did Aboriginal people eat?']

'Wanyu! Kubara, jana! ['Those Chinamen that's what!']

Can't be! (laughs) Reckons minya ngulkurr! [good meat]

[Norman asks Old Pegas:]

'What about Waybala?'

[Pegas answers:]

'Thembala kakaji!'

Reckon'e too salty, see! Salty.

[Norman:]

[Pegas:]

'What about Kubara?'

'Ooh! Ngulkurr, yala yaua!' ['Very good, like a possum!'] ${ }^{58}$

Can't be! (laughs) Can't be like a possum! Flesh very beautiful.

I bin tell'im:

'No good' (laughs).

Ol'fella says.

'No good you talkin' about [it]. You don't know what it's like. But we bin here. If you bin back there, well you'da eat it too. You wouldn'ta know the difference'. (laughs).

UNIVERSITY OF QUEENSLAND

and

MAREEBA, QUEENSLAND 


\section{BIBLIOGRAPHY}

Arens, W. The man-eating myth: anthropology and anthropophagy. New York, 1979.

Brady, Don, Christopher Anderson and Bruce Rigsby. "Some of us are still alive": The Palmer River revisited', A ustralian Institute of Aboriginal Studies, Newsletter, n.s. (13), 1980:30-36.

Bolton, G.C. A thousand miles away: a history of North Queensland to 1920. Canberra, 1972.

Brown, R.B. 'Chinese on the Gilbert River Gold-field', in History Department, James Cook University. Lectures on north Queensland history, third series. Townsville, 1979:169-180.

Cronin, Kathryn. 'The yellow agony: racial attitudes and responses towards the Chinese in colonial Queensland', in Evans, Raymond, Kay Saunders and Kathryn Cronin. Exclusion, exploitation and extermination: race relations in colonial Queensland. Sydney, 1975:235-340.

Evans, R.L. Charitable institutions of the Queensland government to 1919. Lniversity of Queensland, MA thesis, 1969.

'Aborigines and Europeans in colonial Queensland', in Evans, Raymond, Kay Saunders and Kathryn Cronin. Exclusion, exploitation and extermination: race relations in colonial Queensland. Sydney, 1975:25-146.

Evans, Raymond, Kay Saunders and Kathryn Cronin.Exclusiom. exploitation and extermination: race relations in colonial Queensland. Sydney, 1975.

Holthouse, Hector. River of gold: the story of the Palner River gold rush. Sydney, 1967.

Hughes, I.L. " "A state of open warfare": frontier conflict in the Cooktown area, in History Department, James Cook University. Lectures on north Queensland history, second series. Townsville. 1975: 31-46.

Kirkman, Noreen. 'From minority to majority: an account of the Chinese influx to the Palmer River goldfield, 1873-1876', in Reynolds, Henry ed. Race relations in north Queensland. Townsville. $1978 \mathrm{a}: 237-254$.

- "A snider is a splendid civilizer": European attitudes to Aborigines on the Palmer River goldfield, 1873-1883', in Reynolds, Henry ed. Race relations in north Queensland. Townsville. $1978 \mathrm{~b}: 119-144$.

Loos, N.A. "Aboriginal resistance on the mining, rainforest and fishing frontiers', in History Department, James Cook University. Lectures on north Queensland history, first series. Townsville. 1974:163-176.

May, Cathie. 'The Chinese community in far north Queensland', in History Department. James Cook University. Lectures on north Queensland history, first series. Townsville. 1974:121-138.

'Chinese and Europeans in north Queensland: a study in racial relations'. in History Department, James Cook University. Lectures on north Queensland history, second series. Townsville, 1975:135-146.

'Chinese-Europeans relations in Cairns during the eighteen eighties', in History Department. James Cook University. Lectures on north Queensland history, third series. Townsville. 1978a: 157-168.

'The Chinese in Cairns district, 1876-1920', in Reynolds. Henry. ed. Race relations in north Queensland. Townsville, 1978b:217-236.

Meston, Archibald. 'Memories of the late Archibald Meston (supplied by E. Meston): camnibals and cannibalism', Cummins and Campbell's Monthly Magaine, 5 (116), 1936:73-75.

Queensland Parliament. Debates. 1901:1141;1422.

Queensland State Archives, (QSA) Brisbane, Queensland. Colonial Secretary's bundles: COL/139. $\mathrm{COL} / 140, \mathrm{COL} / 143, \mathrm{COL} / \mathrm{A} 717$.

Roth, Walter E. Food: its search, capture and preparation. Brisbane (North Queensland Ethnography. Bulletin 3), 1901.

Taam Sze Pui. 'The diary of Taam Sze Pui (known in Finglish as Tom Sec Poy)'. Historical Society, Caims, North Queensland, Bulletin. (130). 1970). (Originally published at Imisfail. 1920). 